\title{
Kevätvehnän sakoluvun ennustaminen ja verkkopalvelun rakentaminen
}

Timo Hurme ${ }^{1)}$, Pirjo Peltonen-Sainio ${ }^{2)}$ ja Lauri Jauhiainen ${ }^{3)}$

${ }^{1)}$ MTT, 31600 Jokioinen, timo.hurme@mtt.fi

${ }^{2)}$ MTT, 31600 Jokioinen, pirjo.peltonen-sainio@mtt.fi

${ }^{3)}$ MTT, 31600 Jokioinen, lauri.jauhiainen@mtt.fi

\section{Tiivistelmä}

Vehnän korjuussa ajoitus on erittäin tärkeä. Satoa ei kannata korjata liian aikaisin, koska tällöin puintikosteus ja sen myötä kuivatuskustannukset jäävät korkeiksi. Myöhäisen puinnin riskinä on, että sadon laatuominaisuuksista sakoluku saattaa ehtiä romahtamaan niin alhaiseksi, ettei korjattava sato täytä leipäviljoille asetettavia vaatimuksia.

MTT:ssä on pitkään ylläpidetty sakolukupalvelua, jossa loppukesästä raportoidaan sakoluvun mittaustuloksia usealta paikkakunnalta kaksi kertaa viikossa. Järjestelmän haasteina on sen vaatima suuri henkilötyöpanos sekä rajoitettu maantieteellinen kattavuus. Vuonna 2009 MTT:ssä testikäyttöön otetussa kevätvehnän sakolukua ennustavassa verkkopalvelussa on pyritty vastaamaan näihin haasteisiin ja täydentämään perinteisen sakolukupalvelun tarjoamaa informaatiota. Sakolukuennuste kertoo valitun tähkälletulopäivän ja lajikeryhmän mukaisen ennusteen sakoluvusta. Ennuste päivittyy elo- ja syyskuussa päivittäin ja siten tarjoaa joka päivä tuoretta informaatiota sakoluvun kehityksestä. Lisäksi palvelu on maantieteellisesti kattava, sillä ennustetut sakoluvut esitetään koko vehnänviljelyalueen kattavalla kartalla.

Verkkopalvelussa esitetyt ennusteet perustuvat tilastollisiin malleihin, joiden aineisto on peräisin MTT:n ja Boreal Kasvinjalostuksen kokeista vuosilta 1998-2007. Mallit käyttävät lähtötietoina Ilmatieteen laitoksen $10 \times 10$ kilometrin hilalle laskemaa päivittäistä tietoa lämpötilasta, kosteudesta ja sateesta. Sakolukuennuste on saatavissa ennustetusta dormanssin eli itämislevon murtumispäivästä eteenpäin. Dormanssin murtumishetken sakoluku ennustetaan käyttäen tähkälletulon ja tuleentumisen välisen ajanjakson säätietoja. Dormanssin murtumisen jälkeinen sakoluvun asteittainen lasku ennustetaan käyttäen päivittäistä säätietoa dormanssin murtumispäivästä eteenpäin. Lisäksi palvelu ennakoi mahdollista sakoluvun romahdusta kolmessa eri tulevaisuuden sateisuusvaihtoehdossa. Sääskenaario A kuvaa ajankohtaan nähden kosteaa ja runsassateista ajanjaksoa, skenaario B kuvaa sateisuudeltaan tyypillistä ajanjaksoa ja skenaario C kuvaa kuivaa ja vähäsateista ajanjaksoa. Eri sateisuusvaihtoehdoille tuotetuissa ennusteissa hyödynnetään lisäksi ilmatieteen laitoksen viiden vuorokauden lämpötilaennusteita.

Sakolukuennustetta on MTT:n ja Boreal Kavinjalostus Oy:n lisäksi ollut tuottamassa Vilja-alan yhteistyöryhmä VYR. 


\section{Johdanto}

MTT:ssä on pitkään ylläpidetty sakolukupalvelua, jossa kasvukauden loppupuolella raportoidaan sakoluvun määritystuloksia usealta paikkakunnalta kaksi kertaa viikossa. Määritetyt sakoluvut on julkaistu sekä internet-sivuilla että maaseudun tulevaisuudessa. Tällaisen järjestelmän ylläpito vaatii kuitenkin paljon käytännön työtä ja havainnointimäärät ovatkin vähentyneet viime vuosien kustannuspaineessa. Vaikka havainnointia tehtäisiin useammallakin paikkakunnalla, perinteisen sakolukupalvelun haasteena on työmäärän lisäksi myös maantieteellinen kattavuus. Sakoluku on riippuvainen paikallisista sääoloista, jolloin sakolukuarvion yleistettävyys on vaikeaa, jos havainnointipaikka on kaukana kiinnostuksen kohteena olevasta paikasta. Nyt kehitetyn ennustepohjaisen kevätvehnän sakolukupalvelun avulla saadaan ratkaisuja näihin kahteen vanhan palvelun haasteeseen: kustannustehokkuuteen ja maantieteelliseen kattavuuteen.

Sakolukua on aiemmin mallinnettu esimerkiksi rukiin osalta (Laurila ym., 1991). Sakoluku on kiitollinen mallinnettava, sillä sakoluvun rakentuminen ja romahtaminen kytkeytyvät hyvin vahvasti sääoloihin ja ilmiö lainalaisuuksineen on hyvin tunnettu jo pitkään. Ratkaisevimmat sakolukua säätelevät säätekijät ovat sademäärä, ilmankosteus ja lämpötila. Yhtälön tekee kuitenkin haasteelliseksi lajikkeiden väliset eroavuudet sakoluvussa sekä sakoluvun herkkyydessä reagoida säätekijöihin. Myös lakoontuminen lisää huomattavasti sakoluvun romahtamisen.

\section{Aineisto ja menetelmät}

Sakolukuennustemallin laatimisessa käytettiin pääaineistona perinteisen sakolukupalvelun mittaustuloksia vuosilta 1998-2007. Havainnot oli tehty perinteistä palvelua varten perustetuista koeruuduista, jotka oli sijoitettu yleensä virallisen lajikekokeen tai jonkun muun peltokokeen yhteyteen omaksi ns. sakolukulohkoksi. Kyseinen lohko oli sisältänyt useita koeruutuja, joihin kuhunkin oli satunnaistettu eri lajike. Kustakin ruudusta oli otettu näyte kaksi kertaa viikossa sadonkorjuuajankohdan lähestyessä ja näytteestä oli määritelty lajikkeen sen hetkinen sakoluku. Kuvassa 1 on esimerkki yhdestä mittaussarjasta tehoisan lämpösumman funktiona.

Kuva 1. Sakolukupalvelun mittaussarja Kokemäeltä vuodelta 2001 lajikkeelta Tjalve.

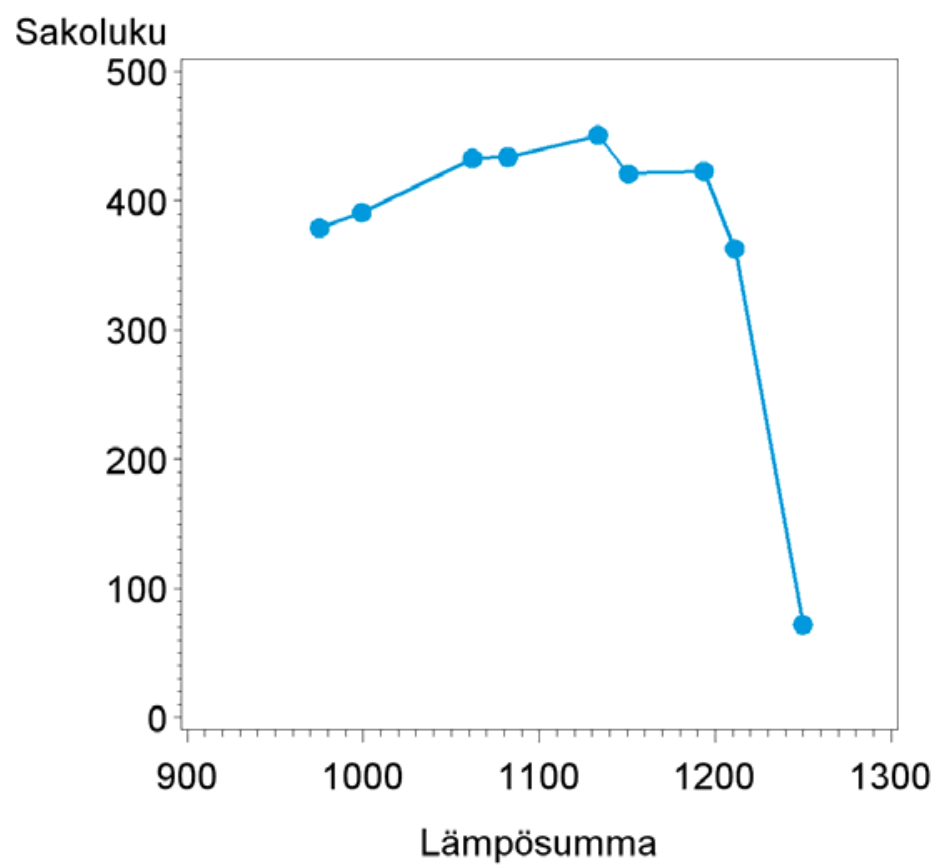

Perinteisen sakolukupalvelun yhteydessä oli tallennettu ainoastaan sakolukutieto, havainnointipäivämäärä ja kosteustieto. Mallin rakentamista varten oli oleellista liittää erinäisiä muita täydentäviä tietoja. Kuhunkin päivämäärään liittyvä tehoisa lämpösummatieto saatiin Ilmatieteen laitoksen toimittamista sääaineistoista, joista poimittiin kyseisen päivämäärän säätieto lähimmältä mahdolliselta sääasemalta. Mallia varten tarvittiin lisäksi sarjakohtaiset kylvö-, tähkälletulo- ja tuleentumispäivät. Jos tarkkaa päivämäärää ei ollut saatavissa, aineistoa täydennettiin ensisijaisesti lajikekoeaineiston tietojen avulla (Kangas ym., 2008), jos läheisyydessä oli ollut samana vuonna kevätvehnän lajikekoe. Lajike- 
kokeen puuttuessa tähkimis- ja tuleentumispäivää arvioitiin keskimääräisen tähkiseen ja tuleentumiseen vaadittavan lämpösumman avulla.

Mallin kehittämisessä olennaista oli selvittää dormanssin eli itämislevon päättymisen ajoittumista suhteessa tuleentumisajankohtaan. Tämä tehtiin käyttäen Boreal Kasvinjalostus Oy:n keräämää kostio-aineistoa, jossa 5 vuorokautta tuleentumisen jälkeen kerättyä satoa oli pidetty $100 \%$ kosteudessa ja 18 Celsius-asteen vakiolämpötilassa. Aineisto sisälsi tietoa lukuisista lajikkeista, joista 10 lajiketta oli esiintynyt myös sakolukupalvelussa, joten lajikekohtaisia erojakin saatiin määritettyä.

Eri lähteistä kerättyjen aineistojen käsittely ja yhdistäminen tehtiin käyttäen SAS-ohjelmiston versiota 9.2 (SAS Institute Inc., Cary, NC, USA). Yhdistettyä aineistoa käytettiin avuksi ennustemallin laatimiseen. Mallin rakentaminen jakaantui kolmeen vaiheeseen:

(1) Dormanssin murtumishetken mallinnus

(2) Sakoluvun ennustaminen dormanssin murtumishetkelle

(3) Sakoluvun asteittaisen romahtamisen ennustaminen dormanssin päätyttyä

Vaiheessa 1 kostio-aineistoon sovitettiin epälineaarinen laskeva Gomperzin-käyrä (Thornley \& France, 2007), jonka avulla estimoitiin lajikekohtaisesti tarvittava lämpösummakertymä tuleentumisesta dormanssin murtumishetkeen. Tämän lämpösummatiedon avulla voitiin lisätä alkuperäisestä sakolukupalvelusta kerättyyn ja lämpösummatiedoilla täydennettyyn aineistoon ennustettu dormanssin murtumishetki.

Mallinnuksen toisessa vaiheessa ennustettiin sakoluvun taso dormanssin murtumishetkelle. Mallin tämän vaiheen rakentamisessa käytettiin perinteisen sakolukupalvelun aineistoa siltä osin kuin havaintoja oli tehty ennen ennustettua dormanssin murtumista. Sakoluvun kehittymisestä tiedettiin etukäteen, että tärkkelyksen kertymisvaiheen aikainen säätila vaikuttaa erittäin paljon siihen, miten korkeaksi sakoluku muodostuu. Ennakkohypoteesina oli, että säätekijöistä vaikuttaisi tässä vaiheessa lähinnä lämpötila, eikä niinkään sade tai kosteus. Tärkkelyksen kertymisjakson aikaisen säätilan vaikutusta sakoluvun kehittymiseen tutkittiin käyttäen satunnaiskertoimisiä regressiomalleja SAS 9.2:n MIXED-proseduurilla (Schabenberger \& Pierce, 2002). Tulos oli ennakkohypoteesin mukainen: säätekijöistä ainoastaan tärkkelyksen kertymisjakson aikaisen keskilämpötilan havaittiin vaikuttavan tilastollisesti merkitsevästi ennustetun dormanssin murtumishetken sakolukuun. Muiden säätekijöiden ohella myöskään lyhyemmät eri ajanjaksot tärkkelyksen kertymisajanjakson sisällä eivät parantaneet ennustetta. Niinpä lopullisessa mallissa dormanssin murtumishetken sakolukua ennustetaan lajikkeen yleisen sakolukutason lisäksi ainoastaan tärkkelyksenkertymisjakson aikaisen keskilämpötilan avulla.

Dormanssin murruttua sakoluku laskee tai jopa romahtaa kosteassa ja lämpimässä säässä. Säätilaa kuvaamaan käytettiin kumulatiivista sääindeksiä. Dormanssin murtumishetkellä indeksin arvoksi asetettiin nolla. Indeksiin lisättiin päivittäin kyseisen päivän ilman suhteellisella kosteudella painotettu keskilämpötila mikäli suhteellinen kosteus oli vähintään $60 \%$. Indeksiin lisättiin myös päivän sademäärä, jolloin etenkin voimakkaat sateet kasvattivat indeksiä. Tämän jälkeen sakoluvun lasku mallinnettiin sääindeksin funktiona käyttäen epälineaarista laskevaan Gaussian-käyrää. Mallinnus toteuttiin kaksivaiheisesti siten, että sakolukupalvelun aineistoon sovitettiin kuhunkin havaintosarjaan erikseen laskeva käyrä ja sitten samaan lajiketyyppiin kuuluvien yksittäisten sarjojen estimoiduista parametreista laskettiin keskiarvot kuvaamaan keskimääräistä sakoluvun käyttäytymistä sääindeksin funktiona dormanssin murruttua.

Edellä mainittujen mallien lopputulemana sakoluvulle saadaan ennuste kasvukauden aikana elettävälle päivämäärälle, kun toteutuneet säätiedot ovat saatavilla. Sakoluvun kehittymistä haluttiin ennustaa myös viisi vuorokautta eteenpäin. Tähän käytettiin Ilmatieteen laitoksen viiden vuorokauden lämpötilaennustetta, joka on varsin tarkka. Sen sijaan ennustettujen sade- ja kosteustietojen käyttö oli epävarmempaa. Niinpä ennustepalvelua varten laadittiin kolme lähitulevaisuuden sääskenaarioita, joiden avulla käyttäjä voi itse kokemuksensa tai säätiedotteen avulla arvioida seuraavan viiden vuorokauden sade- ja kosteustilannetta ja käyttää lähimmäs omaa sääarviotaan osuvaa sakolukuennustetta. Sääskenaario A kuvaa ajankohtaan nähden kosteaa ja runsassateista ajanjaksoa (viiden vuorokauden keskimääräinen suhteellinen kosteus (klo 12) 79 \% ja sadekertymä $50 \mathrm{~mm}$ ). Sääskenaario B kuvaa ajankohtaan nähden sateen ja kosteuden suhteen tyypillistä ajanjaksoa (viiden vuorokauden keskimääräinen suhteellinen kosteus (klo 12) 62 \% ja sadekertymä 8,5 mm). Sääskenaario C kuvaa ajankohtaan nähden kuivaa ja vähäsateista ajanjaksoa (viiden vuorokauden keskimääräinen suhteellinen kosteus (klo 12) 45 \% ja sadekertymä $1 \mathrm{~mm}$ ). 


\section{Tulokset ja tulosten tarkastelu}

Tutkimuksen päätulos on edellä kuvattu ennustemalli, jonka avulla voidaan ennustaa sakoluku erilaisissa sääolosuhteissa. Varsinaisiksi konkreettisiksi tuloksiksi malli muuttuu kuitenkin vasta, kun sitä sovelletaan todelliseen sääaineistoon. Ennustemalli oli testikäytössä kasvukaudella 2009, jolloin eloja syyskuun ajan laskettiin päivittäin uudet sakolukuennusteet. Kunkin tarkastelupäivän kyseisen päivän ennuste laskettiin käyttäen lähtötietoina kasvukauden aikaisia ilmatieteen laitoksen $10 \times 10$ kilometrin hilalle laskemia päivittäisiä toteutuneita säätietoja lämpötilasta, suhteellisesta kosteudesta ja sateesta. Yksittäisiin hilapisteisiin lasketut ennusteet interpoloitiin koko kartalle käyttäen SAS-ohjelmistoa ja tuloksena saatiin kartta (Kuva 2). Kartan piirtäminen edellyyttää, että malliin syötetään tähkimispäivä ja yksi kolmesta lajikeryhmästä (matala, keskisuuri tai korkea sakolukutaso).

Kuva 2. Sakolukuennuste 22.9.2009, kun tähkimispäiväksi on valittu 8.7.2009 ja lajikkeen sakolukutasoksi keskisuuri.
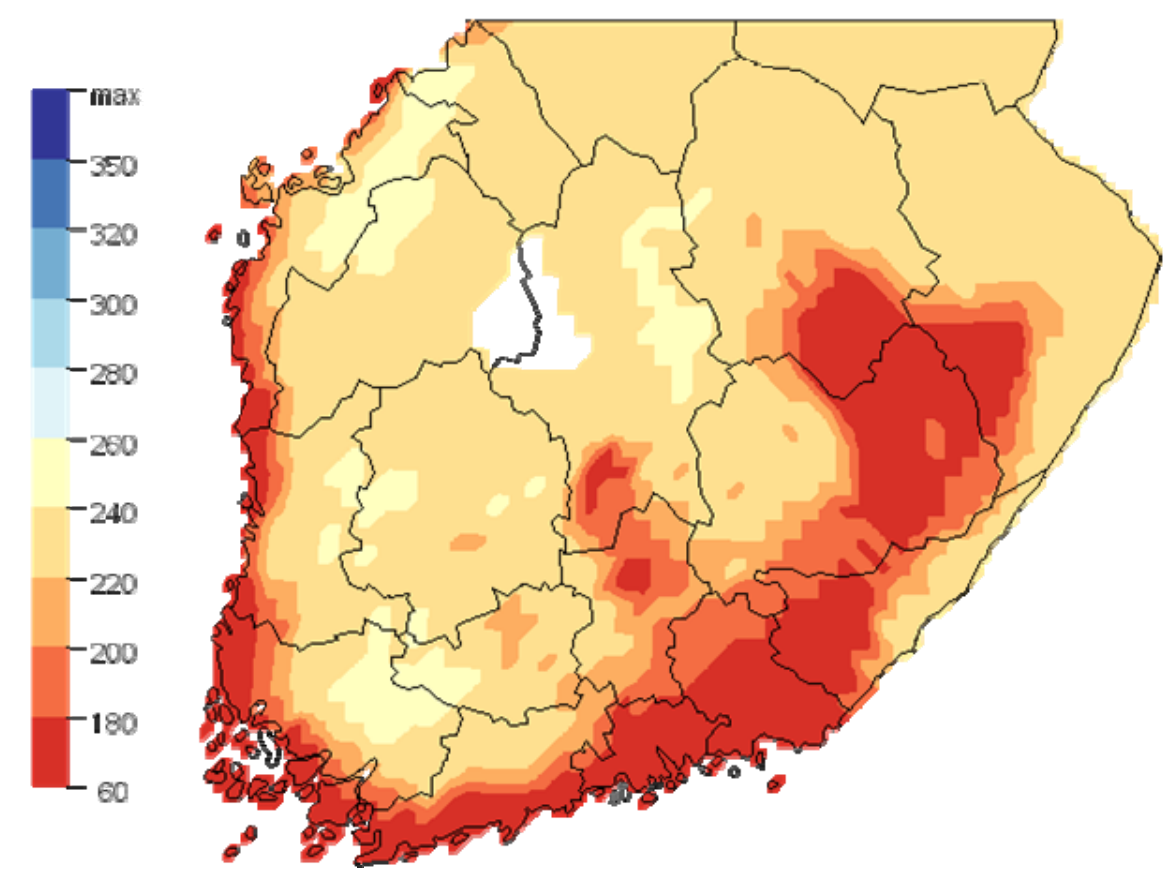

Kolmelle eri 5 vrk sääskenaariolle sakolukuennusteet laskettiin vastaavalla tavalla kuin edellä kuluvalle vuorokaudelle, mutta lähtötietoina kasvukauden aikaiset ilmatieteen laitoksen $10 \times 10$ kilometrin hilalle laskemat päivittäiset toteutuneet säätiedot lämpötilasta, kosteudesta ja sateesta sekä viiden vuorokauden lämpötilaennuste ja näiden lisäksi sateelle ja kosteudelle skenaarion mukaiset arvot. Yksittäisiin hilapisteisiin lasketut ennusteet interpoloitiin koko kartalle käyttäen SAS-ohjelmistoa ja tuloksena saatiin kartat (Kuva 3). 
Kuva 3. Sakolukuennusteet kolmelle 5 vrk sääskenaariolle 22.9.2009, kun tähkimispäiväksi on valittu 8.7.2009 ja lajikkeen sakolukutasoksi keskisuuri.
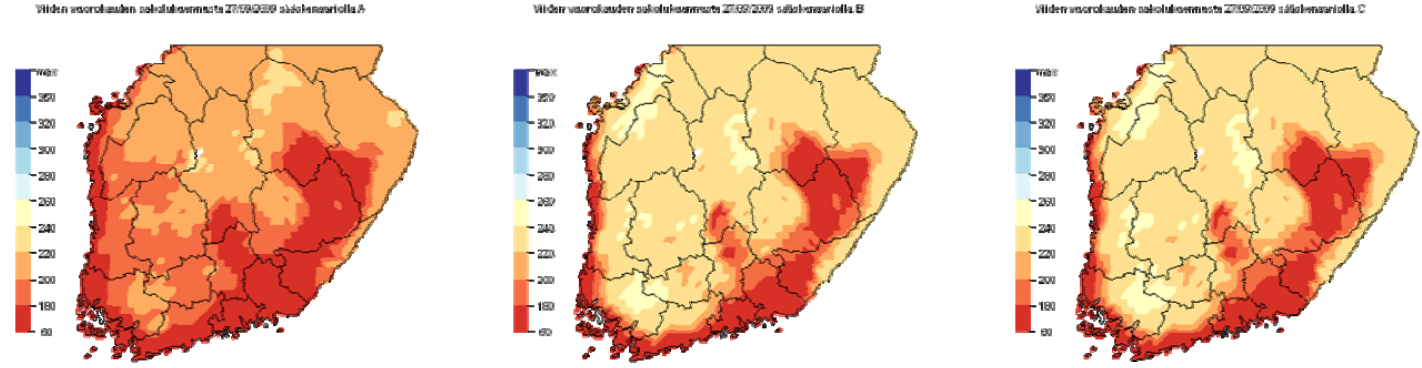

Tulokset esitetään MTT:n yleiselle internetsivupohjalle toteutetulla internetsivulla (Kuva 4). Käyttäjälle annetaan valittavaksi yksi kolmesta tähkimispäivävaihtoehdosta (24.6., 1.7. tai 8.7.) sekä yksi kolmesta lajikeryhmästä (matala, keskisuuri tai korkea sakolukutaso). Valinnoista tähkimispäivä 1.7. vastaa pitkän ajan keskimääräistä tähkimispäivää.

Kuva 4. Esimerkkikuva sakolukuennusteen internet-sivusta

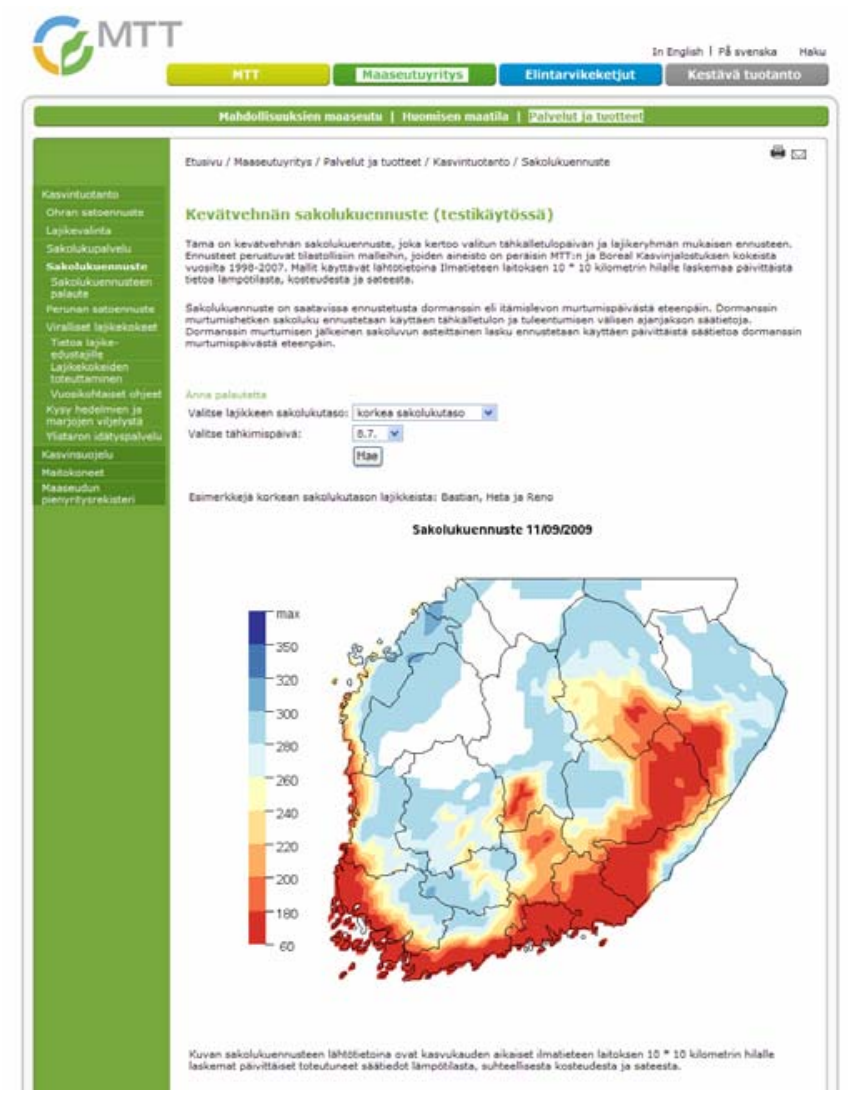

Internet-sivulla esitettävät karttakuvat päivitetään elo- ja syyskuun aikana päivittäin aamupäivän aikana automaattisen SAS-eräajon toimesta, kun viimeisimmän vuorokauden sääaineistot ovat saatavilla.

\section{Johtopäätökset}

Malli on kehitetty kevätvehnälle, mutta vastaavan mallin kehittäminen muillekin kasvilajeille on täysin mahdollista. Kevätvehnän mallia on myös mahdollisuus tarkentaa. Tiedetään, että malli ei aina pysty määrittämään dormanssin murtumishetken sakolukua oikein. Tämä johtaa systemaattiseen virheeseen eli ennustetut sakoluvut ovat säännöllisesti liian pieniä tai suuria. Taustalla on asioita ja ilmiöitä, joista ei ole selvää numerotietoa käytössä jolloin niiden sisällyttäminen malliin on varsin hanka- 
laa. Isoa ongelmaa tästä ei kuitenkaan tule, sillä sakoluvun romahtamisen riski on mallissa riippumaton siitä onko dormanssin murtumishetken sakoluku onnistuttu mallittamaan oikealla tasolle.

Mallissa sakoluvun lasku dormanssin murtumishetken jälkeen perustuu kumulatiiviseen sääindeksiin. Tämä sääindeksi on lämpötilan, sateen ja kosteuden funktio ja siihen on tuskin mielekästä tuoda uusia sääparametreja. Sitä vastoin nykyisten sääparametrien osuutta indeksin laskemisessa voidaan tarkentaa. Olennaista on, että malli pystyy ennustamaan tilanteet, joissa selvä sakoluvun lasku tai jopa romahdus on varsin todennäköinen.

Sakolukuennusteen käyttäjämäärästä saadaan tietoa sivuston näyttökertojen lukumäärän avulla. Käyttäjäseurannan perusteella näyttökertoja oli korjuukaudella eli elo- ja syyskuussa noin 4000. Ennusteen voikin katsoa antavan viljelijöille huomattavia lisävalmiuksia laaturiskien hallintaan.

Nyt viime korjuukauden aikaisen ennustemallin koeajon jälkeen tulemme vertaamaan ennustettuja sakolukuja toteutuneisiin koko ennustejakson ajalta. Lisäksi tutkimusryhmällä on valmius kehittää vastaava ennustejärjestelmä jatkossa myös syysrukiille ja -vehnälle.

\section{Kirjallisuus}

Kangas, A., Laine, A., Niskanen, M., Salo, Y., Vuorinen, M., Jauhiainen, L. \& Nikander, H. 2008. Virallisten lajikekokeiden tulokset 2001-2008 : Results of official variety trials 2001-2008. MTT:n selvityksiä 167: MTT (Maa- ja elintarviketalouden tutkimuskeskus), Jokioinen, 196 s.

Laurila, L., Hiivola, S-L. \& Karvonen, T. 1991. Rukiin sakoluku Etelä-Pohjanmaalla. Tiedote 9/91, Maatalouden tutkimuskeskus, $56 \mathrm{~s}$.

Schabenberger, O. \& Pierce, F.J. 2002. Contemporary statistical models for the plant and soil sciences. CRC Press, Boca Raton, Florida, 738 s.

Thornley, J.H.M. \& France, J. 2007. Mathematical Models in Agriculture: Quantitative Methods for the Plant, Animal and Ecological Sciences, 2nd Edition. CABI, Wallingford, UK, 906 s. 